\title{
Standardization of sieve size for grading of barnyard millet (Echinochloa frumentacea L.) MDU-1
}

\author{
S. Suruthi \\ Department of Seed Science and Technology, Agricultural College and Research \\ Institute, Madurai-625104 (Tamil Nadu), India \\ K. Sujatha* \\ Department of Seed Science and Technology, Agricultural College and Research \\ Institute, Madurai-625104 (Tamil Nadu), India

\section{Menaka} \\ Department of Seed Science and Technology, Agricultural College and Research \\ Institute, Madurai-625104 (Tamil Nadu), India \\ ${ }^{*}$ Corresponding author. E-mail: sujathakvk@gmail.com

\begin{abstract}
Seed grading is an important practice for better crop and also useful in separation of quality seeds in a seed lot. The aim of grading is to improve the uniformity of the seed lot by removing seeds of the same species with low quality. The present study was carried out to find out the optimum sieve size for size grading of seeds of barnyard millet (Echinochloa frumentacea L.) MDU1. The effect of seed size on physiological parameters were evaluated using BSS $10 \times 10$, BSS $12 \times 12$ and BSS $14 \times 14$ wire mesh sieves along with control. The barnyard millet seeds graded with $\mathrm{BSS} 12 \times 12$ recorded higher seed recovery $(76.67 \%)$ than other sieves used with required germination $(92 \%), 1000$ seed weight $(3.9 \mathrm{~g})$, root length $(14.1 \mathrm{~cm})$, shoot length $(8.45 \mathrm{~cm})$, dry matter production (0.027g/10 seedlings) and vigour index (1983). Hence, seeds of barnyard millet MDU1 could be size graded using BSS $12 \times 12$ sieve for more seed recovery with required seed quality standards as compared to BSS $10 \times 10$, BSS $14 \times 14$ and ungraded seeds.
\end{abstract}

Keywords: Barnyard millet, Sieves, Seed recovery, Vigour, Seed quality

\section{INTRODUCTION}

Minor millets are claimed to be the future foods for better health and nutrition security. For a successful crop production, the utility of good quality seeds is very important, which increase the yield by $15-20 \%$. Seed size is one of the important key factor for crop improvement. Due to various seed production environment and cultural practices, the seeds may differ by size, weight, colour and density. To eliminate non seed materials, other foreign seeds and low quality seeds of same species, grading act as an integral part of seed production and enhancing the planting value. Studies pertaining to seed grading based on seed size in relation to seed quality characters are warranted as amount of food reserve in seed is the basic requirement for its future expression as germination, and final establishment at field. In addition to obtain uniform seed size within a variety, size grading is inevitable. Jerlin and Vadivelu (2004) reported that larger seeds having higher seeding survival, growth and establishment. When there is an increased investment in seed size results in de-

\section{Article Info}

DOI:10.31018/jans.v11i2.2096

Received: May 10, 2019

Revised: June 6, 2019

Accepted: June 9, 2019

\section{How to Cite}

Suruthi, S. et al. (2019). Standardization of sieve size for grading of barnyard millet (Echinochloa frumentacea L.) MDU-1. Journal of Applied and Natural Science, 11(2): $524 \quad-\quad 527 \quad$ https:// doi.org/10.31018/ jans.v11i2.2096 creases investments to other functions. Seed size is one of the components of seed quality which affects the performance of crop. (Ojo, 2000; Adebisi, 2004 and Adebisi et al., 2011). The importance of seed size grading in improving physical and physiological quality of the seeds was reported by Suresha et al., (2007) in soapnut; Bicer, (2009) in chickpea; Menaka and Balamurugan, (2008) in amaranthus; Jerlin et al., (2010) in jute; Sadeghi et al., (2011) in safflower; Udhaya et al., (2016) in sunnhemp; Ragupathi, (2017) in proso millet; Sivasubramaniam et al., (2017) in tephrosia and Pozhilarasi et al., (2018) in amaranthus. Therefore, the present study was made in barnyard millet to findout optimum sieve size for grading and its effect on sowing quality of seeds.

\section{MATERIALS AND METHODS}

The bulk seeds of barnyard millet (Echinochloa frumentacea L.) var. MDU1harvested from the crop raised at Department of Seed Science and Technology, AC and RI, Madurai during 2018 served as the basic materials for the present study. The pre-cleaned seeds were size graded 
using sieve sizes BSS $10 \times 10$, BSS $12 \times 12$ and BSS $14 \times 14$ wire mesh sieves (Fig. 1). During size grading, small seeds were discarded which are believed to include empty, underdeveloped and low vigour seeds. The seeds retained in each of the sieves were weighed and expressed as respective percentage of total quantity of seeds processed. The following determination were made on the

above size grades as well as the control (ungraded) viz., 1000 seed weight (International Seed Testing Association, 1999) was determined by recording the mean of eight replications and expressed in gram. For germination percentage, 100 seeds were germinated at the temperature of $25 \pm 1{ }^{\circ} \mathrm{C}$ and $\mathrm{RH} 96 \pm 2 \%$ with diffused light in 4 replications. After 7 days, the seedlings were evaluated and the normal seedlings produced were counted and expressed in percent as per the ISTA (1999). From the germinated seedlings, root length $(\mathrm{cm})$, shoot length $(\mathrm{cm})$, dry matter production (g/10 seedlings) were observed. The vigour index was calculated using the following formula as per Abdul-baki and Anderson (1973) and expressed in whole number:

Vigour index $=$ Germination $(\%) \times$ Total seedling length $(\mathrm{cm})$..........Eq.1

The data collected from various experiments were analysed statistically adopting the procedure described by (Panse and Sukatme, 1985). AGRES software package was used for finding critical differences (CD) values. The critical differences (CD) were calculated at 5 per cent probability level. Wherever necessary, percentage values were transformed to arc sin values before carrying out the statistical analysis.

\section{RESULTS AND DISCUSSION}

Among various post-harvest management techniques, grading plays an important role in improving the uniformity of the seed lot by removing seeds of same species with low quality and thereby resulting in uniform germination with higher planting value. The present study observed that seed recovery of barnyard millet was significantly influenced by size grades. The seeds retained by BSS $12 \times 12$ sieve recorded highest seed recovery of $(76.67 \%)$ than those seeds retained by BSS $10 \times 10$ and BSS $14 \times 14$ sieves of $(11.92 \%)$ and $(9.38 \%)$ respectively (Fig. 2$)$. Where seeds retained by BSS $10 \times 10$ and BSS $14 \times 14$ sieves were on par with each other. The seeds retained by BSS $10 \times 10$, BSS $12 \times 12$ and BSS $14 \times 14$ sieve recorded higher 1000 seed weight and that by BSS $14 \times 14$ passed seeds. 1000 seed weight of ungraded (bulk) seeds and seeds retained by BSS $12 \times 12$ sieves are on par with each other. Several studies like that of Sivasubramaniam, (2008) in kolinji, Menaka and Balamurugan, (2008) in amaranthus; Jerlin et al., 2010 in jute;

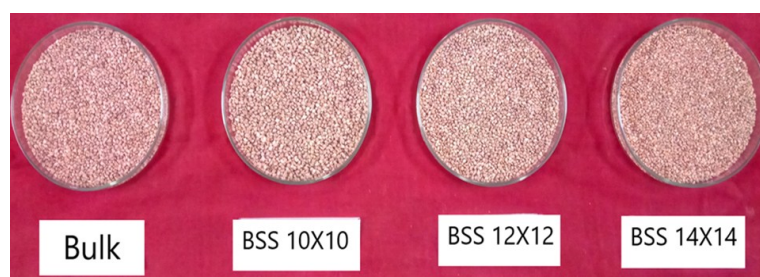

Fig. 1. Seed retained in BSS $10 \times 10$, BSS $12 \times 12$, BSS $14 X 14$ and Bulk of barnyard millet MDU1.

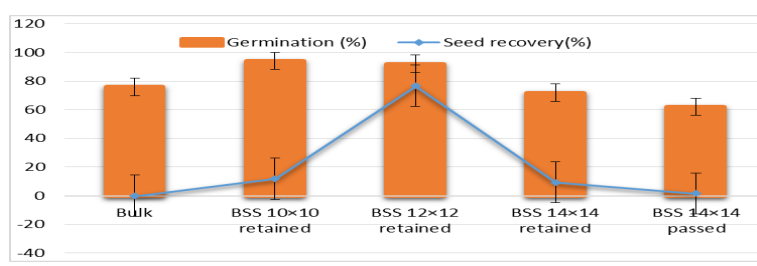

Fig. 2. Effect of size grading on seed recovery (\%) and germination (\%) in barnyard millet MDU1.

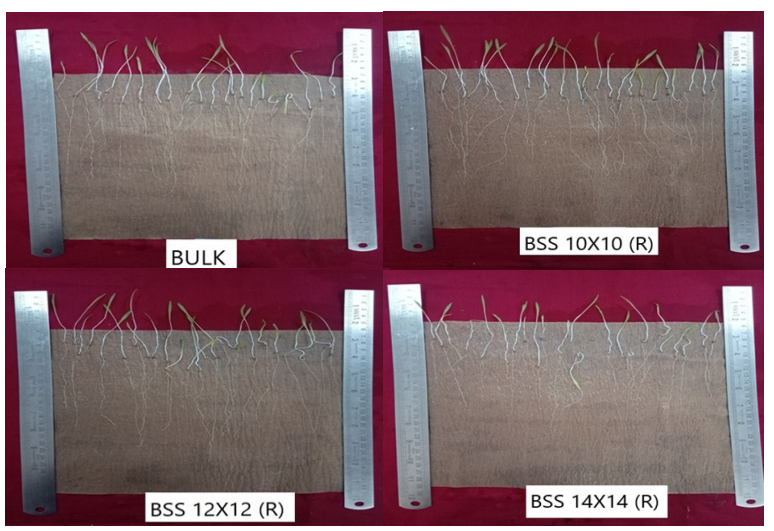

Fig. 3. Effect of germination on size graded seeds using BSS 10X10, BSS 12X12, BSS $14 \times 14$ and Bulk in barnyard millet MDU1.

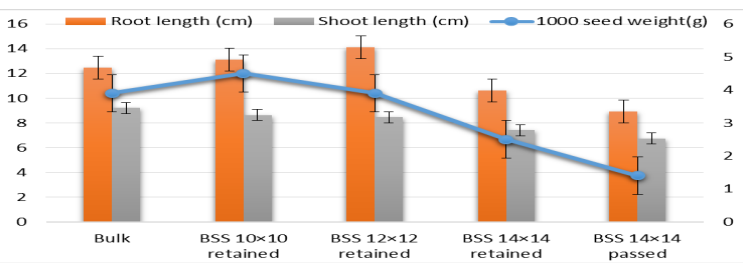

Fig. 4. Effect of size grading on root length $(\mathrm{cm})$, shoot length $(\mathrm{cm})$ and 1000 seed weight $(\mathrm{g})$ in barnyard millet MDU1.

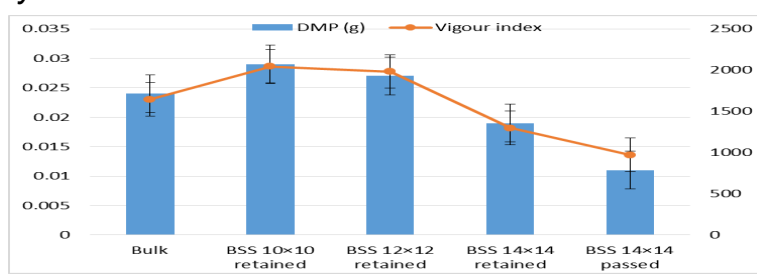

Fig. 5. Effect of size grading on dry matter production (g seedling $\left.{ }^{-10}\right)$ and vigour index in barnyard millet MDU1.

Sadeghi et al., 2011 in safflower; Udhaya et al.,2016 in sunnhemp; Ragupathi (2017) in proso millet; Sivasubramaniam et al., 2017 in tephrosia and Pozhilarasi et al., 2018 in amaranthus report- 
ed a positive association between size and weight of seeds.

The germination capacity increased progressively with increase in seed size. The larger seeds retained by BSS $10 \times 10$ sieve size recorded highest germination $(94 \%)$ followed by the seeds retained by BSS $12 \times 12(92 \%)$ and BSS $14 \times 14(72 \%)$ whereas the control seeds recorded $76 \%$ of germination (Fig. 3). In statistical analysis, seeds retained in BSS $10 \times 10$, BSS $12 \times 12$, BSS $14 \times 14$ sieves and ungraded bulk was recording on par result with each other. The higher germination of larger seeds possessed more vigour than small seeds due to presence of more of food material and increased activity of redox-enzymes helps to breakdown complex food into simple soluble sugars. The results are in agreement with findings of Ndor et al. (2012) in pumpkin; Udhaya et al. (2016) in sunnhemp; Arunkumar et al. (2017) in foxtail millet; Sivasubramaniam et al. (2017) in Tephrosia and Pozhilarasi et al. (2018) in amaranthus.

The other seed quality parameters like root length $(14.1 \mathrm{~cm})$, shoot length $(8.63 \mathrm{~cm})$ dry matter production $\left(0.029 \mathrm{~g} \mathrm{seedlings}^{-10}\right)$ and vigour index (2043) also endorsed the superiority of large sized seeds retained by BSS $10 \times 10$ and BSS $12 \times 12$ sieves (Fig.4 and 5) whereas ungraded bulk seeds(control) recorded rootlength $(12.45 \mathrm{~cm})$, shoot length $(9.2 \mathrm{~cm})$, dry matter production $(0.024 \mathrm{~g})$ and vigour index (1645). Statistically, $\mathrm{T}_{2}$ (BSS $10 \times 10 R$ ) and $T_{3}$ (BSS $12 \times 12 R$ ) was on par with each other and significantly higher than all other treatments in root length, dry matter production and vigour index. Where in shoot length, $T_{1}$ (Bulk), $T_{2}$ (BSS $10 \times 10 R$ ) and $T_{3}$ (BSS 12×12R) was recording on par result and significantly higher than $T_{4}$ (BSS $14 \times 14 R$ ) and $T_{5}$ (BSS $14 \times 14 \mathrm{P}$ ). The seeds passed through BSS $14 \times 14$ sieve were found to be of inferior quality and recorded lower values in all the parameters like seed recovery $(1.67 \%), 1000$ seed weight $(1.4 \mathrm{~g})$, germination percentage $(62 \%)$, root length $(8.92 \mathrm{~cm})$, shoot length $(6 . .73 \mathrm{~cm})$, dry matter production $(0.011)$ and vigour index (970). Due to the greater quantity of storage materials and nutrient reserves available in larger seeds contributed higher energy production. Similar findings were also reported by Farahani et al. (2011) in wheat; Ponmani, (2015) in barnyard millet; Arunkumar et al. (2017) in foxtail millet; Sivasubramaniam et al. (2017) in tephrosia and Pozhilarasi et al. (2018) in amaranthus.

\section{Conclusion}

It was concluded that though barnyard millet seed quality was higher in BSS10×10 retained seeds but the seed recovery was very low. The seeds graded with BSS12×12 recorded higher seed recovery with required seed quality parameters viz., germination $\%$, seedling length, dry matter production and vigour index. Therefore, BSS12×12 sieve could be recommended for size grading of barnyard millet MDU-1 on the basis of the seed quality parameters.

\section{REFERENCES}

1. Abdul-Baki, A. A. and Baker, J. E. (1973). Changes in cellular organelles for membranes related to vigour loss in seed. Seed Sci. \& Technol., 1: 89-125

2. Adebisi, M. A. (2004). Variaation stability and correlation studies in seed quality and yield components of sesame (SesamumindicumL.). Ph. D. Thesis, University of Agriculture, Abeokuta, Nigeria

3. Adebisi, M. A., Kehinde, T. O., Ajala, M. O., Olowu, E. F. and Rasaki, S. (2011). Assessment of seed quality and potential longevity in elite tropical soybean (Glycine Max L.) Merrill grown in Southwestern Nigeria. Niger. Agric. J., 42: 94-103

4. Arunkumar, P., Sadhasivam, K., Sujatha, K. and Sivasubramaniam, K. (2017). "Standardization of sieve size for grading in foxtail millet" paper presented at National Seminar on Emerging trends in Processing and Value Addition of Small Millets, Thamukkam Ground, Madurai. Pg-40

5. Bicer, B. T., (2009). The effect of seed size on yield and yield components of chickpea and lentil. African Journal of Biotechnology, 8 (8): 1482-1487.

6. Farahani, H. A., Moaveni, P. and Maroufi, K. (2011). Effect of seed size on seedling production in wheat (Triticum aestivum L.). Adv. In Env. Bio., 5(7): 17111715

7. ISTA, (1999). International Rules for Seed Testing Seed Sci. \& Technol., Supplement Rules, 27: 25-30

8. Jerlin, R and Vadivelu, K.K. (2004). Effect of fertilizer application in nursery for elite seedling production of Pungam (Pongamiapinnata L. Picrre). J. Trop. Agrl. Res. Extension., 7: 69-71.

9. Jerlin, R., Menaka, C., Raja, K. Moorthy, K.R. and Tamilkumar, P. (2010). Standardization of sieve size for grading of olitorius jute seeds. Asian J. Agric. Res., 4: 15-19.

10.Menaka, C and P. Balamurugan, (2008). Seed grading techniques in Amaranthus cv. CO5. Plant Arch., 8: 729-731.

11.Ndor, E., Dauda, N.S. and Chammang, H.B. (2012). Effect of germination media and seed size on germination and seedling vigour of fluted pumpkin (Telferiaoccidentalis) Hook. F. Adv. Environ. Biol., 2:113-115.

12.Ojo, D. K. (2000). Studies on soybean seed quality and longevity improvement in the humid tropics. Ph. D. Thesis, University of Agriculture, Abeokuta, Nigeria

13.Panse, V.G. and Sukatme, P.V. (1985). Statistical methods for agricultural workers. ICAR Publication, New Delhi, p. 359.

14.Ponmani, T. (2015). Studies on foliar nutrients, seed development and maturation and post-harvest seed handling of barnyard millet (Echinochlo afrumentacea L.). M.Sc., (Ag.) Thesis, Tamil Nadu Agricultural University, Coimbatore.

15.Pozhilarasi, S., Geetha, R. and Sujatha, K. (2018). Effect of sieve size grading for getting better quality seed in Amaranthuspolygonoides var. PLR1. Research Journal of Agricultural Science, 9(5): 11661167 
Suruthi, S. et al. / J. Appl. \& Nat. Sci. 11(2): 524 - 527 (2019)

16.Ragupathi, K.P. (2017). Effect of foliar nutrient on crop growth, seed development, maturation, seed yield, quality and post-harvest handling in Proso millet (Panicum miliaceum L.) cv. CO (PV) 5". M.Sc., (Ag.) Thesis, TNAU, AC \& RI, Madurai.

17.Sadeghi, H., Khazaei, F., Sheidaei, S. and Yari, L. (2011). Effect of seed size on seed germination behaviour of safflower (Cartham ustinctorius L.). J. Agric. Biol. Sci., 6: 5-8

18.Sivasubramaniam, S., Ambika, S. and vetrivel, V. (2017). Influence of size grading on physiological parameters in Tephrosia (Tephrosiapurpurea) MDU
(KO)-1. Journal of Applied and Natural Science 9 (1): $639-641$

19. Suresha, N. L., Balachandra, H. C. and Shivanna, H. (2007). Effect of seed size on germination, viability and seedling biomass in Sapindus emerginatus (Linn). Karnataka Journal of Agricultural Sciences, 20 (2): 326-327.

20.Udhaya, D. (2016). Study of certain seed technological aspects in green manures [sunnhemp (Crotalaria juncea.L), daincha (Sesbania aculeata) and manila agathi (Sesbania rostrata)]. M.Sc., (Ag.) Thesis, TNAU, AC \& RI, Madurai. 